\title{
European Identity
}

\section{PhD. Candidate Greta Bardeli}

\author{
Lecturer, "Luigj Gurakuqi" University, Albania \\ gretabardeli@hotmail.com
}

Doi:10.5901/mjss.2016.v7n2s1p143

\begin{abstract}
Obviously, each culture defines itself in relation to other cultures. In the European Union nowadays the European identity is a status other than a common luck of a certain group of persons or the feeling of a group or culture, person. In the EU, European identity is based on four concepts: EU identity; Europeanisation; Transnationalism; Cosmopolitanism. European identity is a social construction. Europe is a stronger place when its citizens work together both within their states and between them. The two levels of identity - the national and the European - can give Europe's citizens the best of both worlds: patriotic belonging alongside European cooperation and communality. However European identity is about people. It is about connecting European citizens who live within the European Union that share kind of values of democracy, respecting human rights in accordance with the acquis communautaire, an opening free trade market such as free movement of goods, persons, services and capitals.
\end{abstract}

Keywords: European identity, European Union, integration process ect.

\section{Introduction: What is Identity and What do we Understand with European Identity?}

In the European Union nowadays the European identity is a status other than a common luck of a certain group of persons or the feeling of a group or culture, person. There is a rank of definitions of the identity that can give an explanation of its. If we refer to the dictionaries or encyclopedias, we find out that identity is an answer of such questions, like: who am I, who are we, and who are they-the others. The word identity comes from the Latin word "identitas" that means "same" or sameness of the ultimate characters". The identity is clarified by referring to the elements that make somebody different from the others, and by referring to the group identity, which we are interested to treat here, stress out the common things of the group, which make that group different from the other groups, and even though this group may be diverse in itself. So, the identity is an explanation of the individuality in a certain group, which is different from the others. In that way that Weber defines, the identity is a common luck of a certain group of persons. Anyhow, these people should not be necessarily completely same with each-other, but they have got elements that connect them. The identity is the feeling of a group or culture, person, for how much time the last one has had an impact from his/her correspondence in group. The common, characteristics, ideas are clear signs of a common identity, but we should not forget the fact that the identity in its essence has the difference: the feeling of the correspondence in a group and the group defines itself by showing and stressing out that has difference of its with other groups or cultures. The classical answer of the core question is an "union in diversity". And if we consider this answer in the European context, the next one would be: what keeps together the Europeans? What do the Europeans have in common? Which are the differences among them, which not only divide them but also connect them? European identity has been a research topic on the European Commission's agenda since the 1990s. (Euroepan Commission, 2012; Canaj-Bana, 2014: 174) Nowadays the European identity is a status. (Tesauro, 2010: 482) In relation with the European identity, there are two points of view. One is represented by the pessimists who cleave to the essentialism. According to them, this means that the nations and the national identities truly exist. These identities are present in the minds of the people since centuries, like the ideas of Platon. The essential treatment is based on that the nations are considered clear entities and unchangeable. The other thesis is the optimistic one or constructive one. According to this point of view, the communities, nations or groups in general, do not exist separately. The history and politicians gives form or shape them. 'European identity' was the construct of a Europe torn apart by World War-a Europe hard-pressed by the requirement to rebuild its economic and moral strength. 


\section{The Concept of European Identity Today: New Concepts Arising?}

European identity is a social construction. In the EU, European identity is based on four concepts: a) European identity; b) Europeanisation; c) Transnationalism; d) Cosmopolitanism. An important milestone and symbolic in building a European identity is European citizenship, created by the Treaty of Maastricht. From 1 November 1993; in fact, all nationals of a member state of the European Union was recognized, aside his nationality that of Europe. Defined in Article 17 TEU (now Article 20 TFEU) citizen of the European Union is anyone who has the nationality of a Member State. Citizenship of the European Union constitutes an addition to national citizenship and does not replace the national citizenship. Europeans which have dual nationality (that of a Member State and a third country) enjoy the rights deriving from European citizenship. Europeanisation is a construction that refers to a trend towards national institutions. The validity of the concept can be questioned since Europeanisation in reality may be only a peripheral variant of a larger trend of globalisation. Transnationalism is referred to 'cross-borders' whether cosmopolitanism refers to actively seeking out and appreciating contact with other cultures. (Euroepan Commission, 2012).

In the twenty-first century, we have reached a crisis point in the construction of European identity. (Colliver, 2015). Peace and prosperity that apparently underlie what it means to be European are now mutually changing. The EU is under enormous strain due to the financial crisis Constitution that failed and the ratification of the Lisbon Treaty (Canaj Bana, 2014:135) However European identity is about people. It is about connecting European citizens who live within the European Union that share kind of values of democracy, respecting human rights in accordance with the acquis communautaire, an opening free trade market such as free movement of goods, persons, services and capitals. Only with a continued and concerted efforts to engage populations can these positive and precious traits of European identity be renewed and strengthened at this critical situation.

\section{Person Versus Group: One Against the Other}

It is important to clarify the importance of the distinction between individual and collective identification. For the majority of individuals, identity is situational, while very different collective identity tends to be continuous and widespread. This is because collective or group is subject to change difficulties and is patient and strong. Collective identity includes in itself solidarity and is based on "spiritual connection" understood only on a care of meanings, symbols and common backgrounds. When it comes to collective identity should be a distinction between the entire group in itself and the others. Nothing leads to the creation of collective group more than common interests, as may be, for example the common enemy. Similarly, collective identity includes the ability to act and to be responsible for the acts of collective. Individual identity includes the possibility of independent action which enable joint action.

This sense of identity we find at Aristotle, who said that the identity of the Polis was mainly a constitutional identity; "politea" as well, through which the community becomes a political subject. Collective identity in this sense includes a political dimension. Once we have explained the distinction between individual and collective identity, the dimensions and requirements of each category, we can explain better the concept of European identity. Well, European identity is common collective identity that embodies a set of individuals, who are distinct from the others and include the ability and the responsibility to conduct joint.

\section{Identity as Diversity}

Each culture defines itself in relation, or rather, in apposition to other cultures. People who feel they belong to the same culture have these feelings because they rely on general common norms. This means that to determine the meaning of a country's identity through culture need to face this with others. This makes it a distinct culture. However, the premise that humanity has always created close relationships with each others, relationships, from the geographical point of view were also possible in Europe. In this continent, the different cultures are joined to create a common cradle. Of course, in these complex relationships all actors are included: politics, economic, or science and legislation and this different interaction enables the creation of a common identity and distinctive. French philosopher, like Edgar Mori, when talks about European identity refers to "multiple unity" or "Unitas multiplex". Meanwhile, Habermas, defines European citizenship as a creation that comes from different national histories contexts. He brings up the example of Switzerland to illustrate his concept, saying that this is the example of how the political and cultural rights image stands up against the cultural orientations of different nationalities. So, therefore, European identity is rooted to national diversity where countries realize that share a common present and a common future. This happened on the occasion of the creation of a European community or the European Union. For example, taking part in collective action across borders, joining a social movement and sharing together goals can promote the sense of European identity. (European Commission 2012) 


\section{The Identity as Something in Common}

When it comes to European identity, definitely will need to refer to historical base on which it is constructed. Historically, Europe has many roots, that create what can be called political history and cultural identity 'Europe "as a result of specific historical developments and impacts of different paradigmatic figures. The European Union (EU) today is a unification of 28 countries united to create a community from the political and economic point of view within the continent of Europe. Most important roots from antiquity are Athens and Rome. Europe was created by two forces: a continuing influence of these roots in cultural memory and a construction of continuous change from an "other". So, Europe identity is created to differentiate from others. Ethnic, cultural, religious and historical are undoubtedly the most important factors of European identity. This concept has a close relation with early civilizations and their organizations. Though the idea of the EU might sound simple at the outset, the European Union has a rich history and a unique organization, both of which aid in its current success and its ability to fulfill its mission for the 21st Century. Thus, democracy, which has roots in the ancient period, is a characteristic of Europe. There are many other elements, such as: the rule of law, humanity, human individual rights, internal market, foreign and justice affaire and so on. Fundamental rights and parliamentary democracy, which are a reality in the member states of the Council of Europe are undoubtedly the basis of this identity today. The process of European integration is very important as well. One such element is the free movement of persons, which makes you more and more to strengthen a sense of unity. European identity means a very strong commitment to the individual, social cohesion and solidarity. This concept includes in itself a country that respects human rights, and is based on tolerance and the rule of law.

European identity is based on cultural heritage that is a common experience that enabled the creation of a cultural family. European identity is a process that recognizes the existence of differences between individuals, which recognizes diversity and embrace the concept of citizenship, balancing the rights and the duties it entails. The concept of citizenship has been for a long time the central part of European image. EU citizenship is additional to national citizenship and does not replace it. EU citizenship as a distinct concept was first introduced in 1992 by the Maastricht Treaty. The core benefit of being a citizen of an EU state has been that of free movement of person within the territory of the EU. So, one can see European citizenship, as an element that allows the various national identities to coexist in the European Community, but always respecting their differences and their affiliations. The cited Article 20 TFEU stipulates that European Union citizens enjoy the same rights and obligations provided for by the Treaty. In particular we can mention here some basic rights belonging to European citizens: the right to move and reside freely within the territory of member states, according this freedom to all those citizens who are legally established in a Member State (Article 21 TFEU); the right to vote and to be elected in the Member State in case of elections to the European Parliament for example (Article 22 TFEU); the right to diplomatic and consular protection in third countries by the competent authorities of the member countries different from that to which they belong; The right of access to documents of the institutions, bodies and organizations of the European Union, the right of access to European mediators and the right to petition to the European Parliament.

\section{Conclusions}

Obviously, each culture defines itself in relation to other cultures. However European identity is about people and will continue this way. It is about connecting European citizens who live within the European Union that share kind of values of democracy, respecting human rights in accordance with the acquis communautaire, an opening free trade market such as free movement of goods, persons, services and capitals. Nowadays Europe is widely used as a synonym for the EU, as 500 million Europeans (70\%) are EU citizens. At the other side the European institutions are very important to promote and consolidate the idea of 'Europe' and European identity. European identity continuous to have the foundations on European values like respecting human rights, promoting the education and the encouragement of economic and politic integration.

European identity is a process that recognizes the existence of differences between individuals, which recognizes diversity and embrace the concept of citizenship, balancing the rights and the duties it entails. The concept of citizenship is a central part of European image. EU citizenship is additional to national citizenship. EU citizenship as a distinct concept and the core benefit of being a citizen of an EU state has been that of free movement of person within the territory of the EU. So, one can see European citizenship, as an element that allows the various national identities to coexist in the European Community, but always respecting their differences and their affiliations.

Recent developments related to European citizenship, arising precisely from the EU Treaty provisions are very important to define European identity. In particular, the ECJ case law, states that European citizenship today is the fundamental status of citizens in the European Union. 


\section{References}

Canaj E Bana S., (2014) E drejta e Bashkimit Europian, Onufri.

De Weck R., Neither Reich nor Nation-another future for the European union.European Commission,1999.

Edizioni Giuridiche Simone, (2008) Diritto dell'Unione Europea, Aspetti instituzionali e politiche comuni, Napoli,m 311-314.

Euroepan Commission (2012) Development of European identity identities.

Habermas,J., Citizenship and national identity:some reflection on the future of Europe,Praxis International,1992.

Hojelid S., European Intergation and the idea of European identity: Obstacles and Posibilites,University Vaxjo,Sueden ,2001.

Karlsson I., How to define the European indentity today and in the Future,European Commission,1999.

Pombeni P., The international role of the European Union and the Enlargement Process, University of Bologna, October 2002. Strath Bo., A European Identity: To the historical limits of a concept, European Journal of Social Theory.Nr.5(4),London,2002. Talamanca, M., (2010) Diritto dell'Unione Europea, CEDAM, pg.480-485. http:Ilen.Wikipedia.orglwikilCultural identity 